\title{
Vichy France's Collaboration with Nazi Germany
}

\author{
Stephanie Kates* \\ University of Victoria \\ skates@uvic.ca
}

Abstract

During the Second World War in France, a fascist government known as the Vichy Government replaced the Third French Republic. In 1995, the French government publicly admitted that shortly after signing an armistice with Nazi Germany in 1940, the Vichy regime was responsible for implementing racist policies and contributing to the deaths of tens of thousands of people. The purpose of this article is to begin exploring the extent to which the Vichy Government participated and collaborated in the killings, internment, and discrimination of many thousands of people during the Second World War. The following article focuses on three major aspects of the Vichy Government's collaboration: anti-Semitic legislation, the internment camps in France, and the roundup at the Vèlodrome D'Hiver. The case study of the Vèlodrome D'Hiver alongside the other aspects of collaboration are illustrative examples that offer new insights suggesting that Vichy France's government operated as an emphatic collaborator with Nazi Germany rather than simply submitting to or passively assisting this administration. The article's thesis advances the notion that this emphatic collaboration was implemented mostly without direction or instruction from the authorities of the Nazi occupying forces.

Keywords: Vichy France; Nazi Germany; Second World War; anti-Semitism; collaborationist

$\mathrm{I}$ n French history, both the French Resistance and its defiance against the Axis powers during the Second World War hold great weight in the public's imagination and remembrance. In the French "collective memory," a "Myth of Resistance" perpetuated by Charles de Gaulle took precedence in defining the roles and positions French governments, scholars, and the public adopted after the Second World War (Collins-Weitz, 1995, p. 305). French historian Henry Rousso coined the term "Résistancialisme," a term illustrating the myth of the significance and extent of French resistance during the Second World War. He argued that this myth emerged post-war and described the widespread impression of unanimous resistance during the war period. In his review of Douglas Porch's book on the French Resistance, Bernard Kaplan cites Porch and writes that in reality "only about 5 percent of the French were even nominally members of the underground. Of these, scarcely any ever fired a shot in anger, dynamited a train or sent a clandestine radio message" (1996, para. 6). The French government officially recognized only 220,000 male and female resistors (Collins-Weitz, 1995), less than $1 \%$ percent of the wartime population. An opposing aspect to France's promulgated myth of resistance is the Vichy government's willing participation in the mass genocide and persecution of minority groups in Europe during the Second World War.

Although it is relatively well-known that the Nazi party in Germany introduced discriminatory laws against those whom they classified as undesirable, it has also been established that the Vichy Government in Second World War France devised similar laws to isolate what they considered to be dissimilar or incompatible racial, national, religious or opposing political groups (such as the

\footnotetext{
${ }^{*}$ I would like to thank Dr. Charlotte Schallié for her invaluable guidance, encouragement, inspiration and feedback over the past four years, and Jamie Cassels Undergraduate Research Award for funding this research.
} 
French Communist Party). Both the Vichy Government in France and the Nazi party in Germany were ultra-nationalistic and shared many common racial and societal values. Not only was this newly-established government in France fundamentally right wing, but they introduced anti-Semitic laws, built and controlled internment camps for "undesirables," and instigated a roundup of more than one-quarter of France's native and refugee Jewish population, including women and children, against previous Gestapo orders to round up only fit men. This government of France chose to implement certain Nazi-like policies in ways that were independent from Nazi administrative orders, yet served a common goal. Three historical examples are examined to offer insight into the nature of these government actions: the implementation of anti-Semitic legislation, the internment camps in France, and a case study of the roundup at the Vélodrome D'Hiver. These examples suggest that Vichy France's government operated as an emphatic collaborator with Nazi Germany. This article contributes to the argument made by scholars such as Michael Marrus, Robert Paxton, and John Merriman that the Vichy government collaborated largely on their own authority, rather than simply cooperating with or obeying the orders of their occupier.

\section{Collaboration versus Cooperation}

The difference between the two words "collaboration" and "cooperation" can be both subtle and ambiguous. By definition, these words are rather similar; however, their connotations are extremely different. The etymologies of the words are quite comparable as well-collaborate coming from the Latin word "collaborare" or "to labor together" ("Collaborate," n.d.) and cooperate coming from the word "cooperari" or "to work together" ("Cooperate," n.d.). However, in modern English, cooperation can be defined as "the actions of someone who is being helpful by doing what is wanted or asked for" ("Cooperation," n.d.), while collaboration is defined as "a purposeful relationship in which all parties strategically choose to cooperate in order to achieve shared or overlapping objectives" (Rubin, 2009, p. 2). The word collaboration is typically employed when describing active participation, whereas the word cooperation comes from a passive appeasement. Furthermore, as Yale history professor John Merriman said, "the term collaboration took on a less neutral meaning ... because of the experience of countries like France, in the Second World War, where ... people actively helped the Nazis achieve their goals. So, collaboration took on this sort of sinister term as well" (2007, 10:31). Since the events and actions discussed in this paper originated with and were implemented by the Vichy government, the words "collaboration" and "collaborationist regime" ("France Opens Archives," 2015, para. 2) are thought to be more a more accurate descriptor of this administration's actions than the word cooperation. In fact, the term collaboration has been used frequently in discussions regarding the Vichy regime in historical literature since 1940 in order to emphasize the ways that the government acted autonomously. According to Marrus and Paxton, "Vichy France bears an important part of the responsibility for this disaster" (1981, p. xv) since the explicit, active, and rapid implementation of anti-Semitic laws and willingness to cooperate with Nazi policies better fit the criteria of active participation than passive appeasement. Therefore, the term collaboration rather than cooperation describes how these two governments worked independently towards a common end.

\section{Pétain's Government and Armistice with Hitler}

Prior to discussing the contextualizing information and illustrative historical examples, it is important to review the historical conditions that set the stage for the Vichy regime to assume power. The fascist period in France was defined by certain ideologies and movements, and "it was in France that the radical right soonest acquired the essential characteristics of fascism, and it was in France, 
also, that this process was most rapidly completed" (Sternhell, 1986, p. 1). Not only did the Great War play a significant role in the birth of fascism in France, but social and political conditions such as "widespread unemployment, an impoverished middle class, [and] a terrorized petite bourgeoisie" and nationalist or racist ideology contributed to the popularity of right-wing regimes during the interwar period (Sternhell, 1986, p. 1). This growing popularity of the right contradicted the traditional form of liberal democracy in France at the time and led to the undemocratic appointment of, yet undercurrent of support for, a new leader during the Second World War. In June 1940, consequently, Maréchal Philippe Pétain, an 84-year-old retired war general, was granted the leadership of a new right-wing Vichy government that replaced the Third French Republic upon recommendation of the preceding President Albert Lebrun. On June 22nd, this new government brought an end to the Battle of France by quickly formulating and signing an armistice with Nazi Germany in a train car located in the forest of Compiègne. This armistice also served to appease Hitler while maintaining a certain degree of independence for France (Marrus, 1995). From 1940 to 1942, France was considered a client state of Nazi Germany (Rosbottom, 2014).

The country was divided in three parts according to the second and third articles of the convention (Franco-German Armistice, 2008). The north half of the country was under the occupation of the Germans and labelled the "Occupied Zone," with the exception of a small region in northeastern France annexed to Belgium and labelled the "Forbidden Zone." The newly established rightwing Vichy government assumed power over the southern half of France, which was labelled the "Unoccupied Zone." The headquarters of this professed "Vichy government" were located in the town of Vichy in southern France and thereby infamously resulted in the government being renamed (Jackson, 2001). This government enacted a series of policies that represented three main promulgated values: Catholicism, family, and work. It was an idealized state epitomized in the following quote: "true France is what they called it, true France, the real France, not the France of Jews, not the France of grèves - no strikes, strikes [were] illegal. Not the France of working class organizations, no CGT, organized workers need not apply, need not exist, et cetera" (Merriman, 2007, 47:50). The Vichy administration changed France's motto from liberty, fraternity, and equality to family, work, and country, yet kept the revolutionist anthem La Marseillaise, originally a revolutionary song that held ties to the more subversive aspects of France's past (Jackson, 2001). The government also introduced a secret police called the "Milice" (Jankowski, 1991) that enacted the more severe forms of the Vichy government's fascist ideologies and eventually carried out various crimes against humanity, such as murder, extortion, surveillance, and torture. The purpose of the secret police was "to get tough on the Jews, get tough on the resistors, get tough on the communists - and these were some of the worst of the collaborators" (Merriman, 2007, 29:08). Under the leadership of a war general (Rosbottom, 2014), the Vichy government is noted as one of the cruelest fascist regimes during the Second World War to legitimately sanction racist government guidelines and policies.

\section{Vichy Government and their Anti-Semitic Policies}

The independent enactment of racist policies is one of the central examples that demonstrate the collaborative nature of the Vichy Government. In the fall of 1940, a series of anti-Semitic laws were created without any instruction from the occupying Nazi government and introduced within three to six months of the Vichy Government coming into power (Marrus \& Paxton, 1981). Legislative changes were introduced three months after inauguration and began with the "abolition on August 27, 1940 of the 'Marchandeau Decree"' (Poznanski, 1992, p. 118), which repealed prior laws against anti-Semitism in the media. In the beginning period of the regime, "the bulk of [the Vichy government's] statutory work was directed to denaturalization policy" (Weisberg, 1996, p. 37). The first statutory initiatives worked towards defining who was a Jew within a bureaucratic and 
political apparatus and "set the tone for all subsequent religious legislation" (Weisberg, 1996, p. 39). The next laws came with "confiscating property belonging to Jews, [along with] restricting their movements" (Marrus \& Paxton, 1981, p. xv). Pre-war works by French authors Pierre Gaxotte, Marcel Jouhandeau, Paul Morand, and Charles Maurras, leader of the Action Francaise (Jackson, 2001), echoed anti-Semitic sentiments that were embraced by both politicians and supporters of their anti-Semitic laws. The political and cultural environment of the time encouraged the denouncement of Jews and resuscitated pre-1930 anti-Semitism, resulting in a lack of outcry about, or repeal of, any racist legislation. "Hugely successful" right wing political groups converged with a rising unemployment rate and an influx of refugees to inflame intolerant attitudes and contributed to changes in the inter-religious atmosphere of Depression-era France (Millington, 2012, para. 5). Regardless of whether anti-Semitism was a large proponent of their political platform or not, the "Vichy [Government] was publicly and conspicuously anti-Semitic" (Marrus \& Paxton, 1981, p. xvi) and made no secret of the fact that they wished to create what they saw as a truer, purer France.

Beginning in October 1940, the Nazis ordered that all foreign and national Jews were to register with the French police, and shortly afterwards, those lists and files were handed over willingly to the Gestapo and SS (Rosbottom, 2014). Jews were then forced to identify themselves with the stamp of "Juif" on their identity cards and were forced to wear Star of David armbands and patches on their clothing. Eventually, Jews were banned from certain public places and subsequently forbidden to practice certain professions such as medicine or law (Rosbottom, 2014). A huge public discourse emerged around the origin of Jews who had emigrated from other countries such as Germany and whether they would have the same rights as those who were French Jew nationals. Related to this discourse, "time and time again [there were] examples of internal debate, impervious to German influence, on crucial questions of Vichy racial policy" (Weisberg, 1996, p.43).

In addition, the new Vichy government had created a "Committee on the Jewish Questions" (Commissariat général aux questions juives) in 1940 that was led by Xavier Vallat (Weisberg, 1996, p. 78). With the exception of ordering the registration of Jewish persons, "none of these actions were forced upon by the [Nazis]; on the contrary ... the [Nazis] noted the rapidity and scope of French legislation with bemusement, opportunistic glee, and even occasional annoyance" (Weisberg, 1996, p. 38). The Vichy Government was in fact "eager to legislate, [and] prideful of tracking its own course on questions of race" (Weisberg, 1996, p. 46). These sets of laws and policies contributed to the hostile anti-Jewish environment of both Northern and Southern France after the Vichy government obtained power, without excessive force or extortion from the Nazi regime. This political atmosphere created fertile conditions for the future internment camps that provide a second historical example.

\section{Internment Camps in Second World War France}

During the First World War, France was home to a number of internment camps that were set up for many different uses; housing prisoners of war and refugees were the most widespread and common. On October 4th, 1940, the Vichy Government legalized "the internment of stateless Jews" in these camps (Weisberg, 1996, p. 37) in addition to a substantial number of other peoples labelled "undesirable." However, after the introduction of Vichy anti-Semitic policy and the initial collaboration with Nazi occupying forces, the internment camps were primarily used for interning a specific subset of the "undesirables" (Bernadot, 2008, p. 12), which were foreign and native Jews, before they were shipped off to Nazi death camps in Alsace, Germany, and Poland. The most well-known were the Drancy and Beaune-la-Rolande camps (Rosbottom, 2014), located mainly in the urban centers throughout various regions of France, which housed many "thousands of Jews" ("The Holocaust," 2017, para. 2), before deporting them to Auschwitz, particularly after the roundup of 1942 ("The Holocaust," 2017). These camps had horrendous living conditions that paralleled 
conditions in the Nazi camps. The French camps had "faulty sanitary facilities," and food provisions could not "sustain even a bare minimum of existence" ("Concentration Camps," 2017, para. 3). The prisoners had neither the ability to appeal their internment nor to allay the conditions, and hundreds died "due to disease, cold and starvation; thousands of prisoners reached a state of malnourishment" ("Concentration Camps," 2017, para. 3).

The internment camp Drancy in particular was originally under the control of the French police until July 3rd, 1943, when it reverted to the leadership of Alois Brunner, a Schutzstaffel (SS) officer. The French police carried out additional roundups of both native Jews and Jewish refugees throughout the war without the instruction or management of the Nazi occupying forces ("Drancy," n.d.). The camp Beaune-la-Rolande was shut down on August 4th, 1943 "by [the same leader of Drancy] SS-Hauptsturmführer Alois Brunner ... under direct orders from Heinrich Himmler" in order to use Drancy as the primary camp and streamline operations (Wieviorka, 2000, p. 31). These internment camps were built and completely run by the French police forces and the Vichy government, making this administration responsible for deporting thousands of Jews to their eventual execution and aiding the Nazi party in exterminating millions of people.

\section{The Roundup of 1942}

An indisputably important historical event in France's past, presented here as a case study, further establishes the Vichy regime's participation in and culpability for Second World War crimes. In the summer of 1942, over 14,000 French native and refugee Jews were taken from their homes, arrested, and brought to the Vélodrome D'Hiver in the 15th arrondissement of Paris. The roundup was ordered by the Nazis, but was executed by French police forces. These forces additionally rounded up women and children even though this was not part of the Gestapo order (Marrus \& Paxton, 1981). The arrestees were forced to turn off any gas, water, and electricity to their homes and give their keys and pets to their landlords (Marrus \& Paxton, 1981). They were transported to and locked inside the Vélodrome in inhumane conditions that lacked food, water, proper toilets and sanitation, healthcare, or personal belongings. Occupants often suffered from malnutrition, dehydration, and sickness (Rosbottom, 2014). The Vélodrome was extremely noisy due to loudspeaker announcements regarding deportations to internment camps and the chatter of "the thousands waiting in the Vél D'Hiv to find out their fate" (Rosbottom, 2014, p. 280). The arena was continuously lit by fluorescent lighting. After temporary internship in the Vélodrome, the arrestees were expulsed to the Drancy or Beaune-la-Rolande internment camps before being transported further to Auschwitz in Poland. Of those 14,000 rounded up and deported, only 811 survived after the war (Marrus \& Paxton, 1981). In the Vélodrome, suicide was extremely common, even in pregnant mothers, who jumped from bleachers to avoid a more humiliating death at the camps (Merriman, 2007).

It was not until 1995 that the modern French government, under the leadership of Jacques Chirac, "officially recognized the French state's responsibility in the deportation of Jews" and their involvement during those war years ("France Opens Archives," 2015, para. 2). Although the original idea of a roundup was conceived by the Nazis, the Vichy government and the French police were eager to participate independently in the roundup, expanded the age range, included women and children, and were responsible for the inhumane conditions and treatment in the Vélodrome. This historical event demonstrates the Vichy government's willingness to implement their own anti-Semitism within these roundup policies. 


\section{Conclusion}

The Vichy government's actions, viewed by scholars such as John Merriman, Michael Marrus, and Richard Weisberger as acts of collaboration, were largely executed on their own authority and by their own legislation. The Vichy government had their own laws and statutes regarding race

and citizenship imposed on July 16th, 1940, yet these policies intensified and progressed alongside the bond with Nazi Germany and at the same time as the right wing Vichy government became stronger and strove to maintain independence. Internment camps, created and run by the French Vichy government, were changed from their original usage for Prisoners of War during the First World War and used to house so-called "undesirables." The roundup was a mass extermination that eliminated the majority of the French Jewish population. The full extent of the roundup was not solicited by the Nazis, particularly the inclusion of women and children, as well as the poor conditions in which the interns lived. Although the Nazi party did have some input into the affairs of the Vichy government, the majority of these policies were introduced through the government themselves without direction. Rather than simply follow orders of Nazi Germany, members of the Vichy government largely participated as emphatic collaborators in the European racial genocide of the Second World War. 


\section{References}

Bernadot, M. (2008). Camps d'étranger. Paris: Terra.

Collaborate [Def 1]. (n.d.). In Merriam Webster Online. Retrieved from https://www.merriamwebster.com/dictionary/collaborate

Collins-Weitz, M. (1995). Sisters in the resistance-How women fought to free France 1940-1945. New York: John Wiley \& Sons, Inc.

Concentration Camps in France [Encylopedia Article]. (2017). Retrieved from http://www.yadvashem. .org/holocaust/france/camps-in-france

Cooperate [Def. 1]. (n.d.). In Merriam Webster Online. Retrieved from https://www.merriamwebster.com/dictionary/cooperate

Cooperation [Def. 1]. (n.d.). In Merriam Webster Online. Retrieved from https://www.merriamwebster.com/dictionary/cooperation

Drancy. (n.d.). [Encyclopedia article]. Retrieved from https://www.ushmm.org/wlc/en/article.php? ModuleId=10005215

France opens archives of WW2 pro-Nazi Vichy regime. (2015, December 28). [Newspaper article]. Retrieved from http://www.bbc.com/news/world-europe-35188755

Franco-German Armistice: June 25, 1940. (2008). [Online Library Document]. Retrieved from http://avalon.law.yale.edu/wwii/frgearm.asp

Jackson, J. (2001). France: The dark years, 1940-1944. Oxford: Oxford University Press.

Jankowski, P. (1991). In defense of fiction: Resistance, collaboration, and Lacombe, Lucien. The Journal of Modern History, 63(3), 457-482. doi:10.1086/244352

Kaplan, B. (1996, January 21). The French Resistance Myth. Retrieved from http://www.sfgate.com /ews/article/The-French-Resistance-myth-3160032.php

Marrus, M. R. (1995). Coming to terms with Vichy. Holocaust and Genocide Studies, 9(1), 23-41. doi:10.1093/hgs/9.1.23

Marrus, M. R., \& Paxton, R. O. (1981). Vichy France and the Jews. New York: Basic Books.

Merriman, J. (2007). Vichy France. [Video file]. Retrieved from http://oyc.yale.edu/history/hist$276 /$ lecture-18

Millington, C. (2013). Vichy France, the Nazis and the Holocaust: An introduction. Retrieved from https://frenchhistoryonline.com/vichy-france-and-the-second-word-war/vichy-francethe-nazis-and-the-holocaust-an-introduction/

Poznanski, R. (1992). The Jews of France and the statutes on Jews, 1940-1941. Yad Vashem Studies, 22, 115-146. Retrieved from http://www.yadvashem.org/yv/en/education/courses/life_ ghettos/pdfs/reading5.pdf

Rosbottom, R. C. (2014). When Paris went dark: The city of light under German occupation, 1940-1944. Boston, MA: Little, Brown and Company.

Rousso, H. (1990).Le Syndrome de Vichy: de 1944 à nos jours (2nd ed.). Paris, France: Seuil.

Rubin, H. (2009). Collaborative leadership: Developing effective partnerships for communities and schools (2nd ed.). Thousand Oaks, CA: Corwin.

Sternhell, Z. (1986). Neither right nor left: Fascist ideology in France (D. Maisel, Trans.). Retrieved from https://quod-lib-umich-edu.ezproxy.library.uvic.ca/cgi/t/text/text-idx?c=acls;idno=heb 01320.0001 .001

The Holocaust in France. (2016). [Encyclopedia article]. Retrieved from http://www.yadvashem.org /yv/en/holocaust/france/deportations.asp

Weisberg, R. H. (1996). Vichy law and the Holocaust in France. Studies in Anti-Semitism, 3. doi: 10.4324/9781314078014 
Wieviorka, A. (2000). Les Biens des Internés des Camps de Drancy, Pithiviers et Beaune-laRolande. Mission d'étude sur la spoliation des juifs de France, 5, 1+. Retrieved from http://www.ladocumentationfrancaise.fr/var/storage/rapports-publics/004001395.pdf 